\title{
Behavior and Stereotypies of Nile Tilapia (Oreochromis niloticus) in Response to Experimental Infection with Aeromonas hydrophila
}

\author{
Fatma Khalil iD, Hosney Emeash iD
}

Cite this article as: Khalil, F., Emeash, H. (2018). Behaviors and Stereotypies of Nile Tilapia (Oreochromis niloticus) in Response to Experimental Infection with Aeromonas hydrophila. Aquatic Sciences and Engineering, 33(4): 124-130.

Animal and Poultry Management and Wealth Development, Beni-Suef University, Faculty of Veterinary Medicine, Beni-Suef 62511, Egypt

Submitted:

16.03.2018

Accepted:

27.08.2018

Correspondence:

Fatma Khalil

E-mail:

fatmahs77@yahoo.com,

fatma.khalil@vet.bsu.edu.eg

(C) Copyright 2018 by Aquatic

Sciences and Engineering

Available online at

ase.istanbul.edu.tr

\begin{abstract}
Motile Aeromonas septicemia (MAS) is a common bacterial fish disease that may cause severe economic losses. This novel study was conducted to investigate behavioral changes of Nile tilapia (Oreochromis niloticus) in response to experimental induction of MAS. Aeromonas hydrophila, which is the causative agent of MAS, was isolated from diseased $O$. niloticus and used for the experimental infection of $O$. niloticus by intraperitoneal and intramuscular injections for inducing MAS. Each injection route had its control group. Fish behavior was recorded daily using a digital video camera for 7 consecutive days post injection in intraperitoneally and intramuscularly injected fish. On day 14 post injection, the behavior of intramuscularly injected fish was recorded again. Experimentally infected $O$. niloticus showed various clinical signs such as exophthalmia, ocular hemorrhage, congested gills, and skin and fin hemorrhages. The behavior of apparently healthy and experimentally infected $O$. niloticus was recorded and analyzed by scan observation. The experimentally infected fish exhibited cessation of normal behavior. Buccal-opercular movement and signs of aggression increased, whereas foraging, schooling, and shoaling frequencies decreased. Two abnormal behavioral patterns (stereotypies) of apparently healthy $O$. niloticus following injections were recorded. Post injection, intraperitoneally injected fish performed circular swimming on day 3 and 7 , whereas intramuscularly injected fish exhibited vertical movement on the days 4, 5, 7, and 14. The frequency of circular swimming increased over time; however, vertical swimming frequency decreased by day 14 . These results revealed that MAS had a severe effect on the behaviors of apparently healthy fish. Therefore, monitoring the behavior of $O$. niloticus may provide a useful and noninvasive tool for assessing fish health and diagnosing MAS early.
\end{abstract}

Keywords: Fish behavior, stereotypies, motile Aeromonas septicemia, Nile tilapia

\section{INTRODUCTION}

There is an increasing demand on fish meat world-wide due to its high quality and healthy protein content and hence aquaculture industry showed a significant development in the last decades. However, bacterial diseases may threaten this industry due to serious impacts such as retarded growth or mortalities which cause economic losses. Motile Aeromonads septicemia (MAS) is one of the most virulent bacterial fish disease in cultured fishes, especially Nile tilapia Oreochromis niloticus (Pa- vanelli et al., 2008; Pridgeon and Klesius 2011 and 2012; El-Araby et al., 2016).

Fish behavior reflects the biochemical and physiological changes induced by stress and/or disease conditions. Therefore, it can be used as an early indicator to the health status of fish (Martins et al., 2012). In addition, it is targeted to predict economic impacts of diseases and stress on the aquaculture. Moreover, behavior is fast and easy to observe (Martins et al. 2012). Thus, it provides a useful tool for assessment of fish health and early diagnosis of diseases in cultured fish. 
Ventilatory activity, achieved with bucco-opercular movements, is measured by the flow of ventilated water over gills per unit time (Martins et al., 2012). This renewal of oxygenated water is well regulated in healthy fish (Martins et al., 2012). Foraging behavior is the search for and exploitation of food resources (Danchin et al., 2008). Common types of social behavior in fish are, shoaling, schooling and aggression (Pavlov and Kasumyan, 2000). Shoaling refers to fish that swim together in an unstructured pattern, whereas schooling implies synchronized and polarized swimming (Faucher et al., 2010). In addition, the swimming of three fish together is described as shoaling and four and more fish swimming together is called schooling (Khalil et al., 2013). Impairment of foraging frequency and social interactions of these behavioral patterns may threaten the survival of fish in an ecosystem.

Stereotypic behavior is defined as a behavioral pattern that is repetitive invariant, and are frequently indicative of an sub-optimal environment (Mason, 1991). Furthermore, stereotypic behavior is believed to be an adaptation to stress (Vestergaard, 1981; Anonymous, 1989). Common stereotypical behaviors in fishes are circular swimming ; fish swimming in fixed circular pattern for more than $20 \mathrm{sec}$ (Almaza'n-Rueda et al., 2004) and vertical swimming; fish swimming vertically with head broke the water surface) (Kristiansen and Fernö, 2007). Thus, observation of these two stereotypies are performed by fish is an indication of stress.

Experimentally induced infections of MAS by intramuscular and/ or intraperitoneal injection were studied in several fish species including Nile tilapia; O. nilticus (Banu and Yılmaz, 2011), catfish; Clarias gariepinus (Korni, 2015; Korni et al., 2016), Pangasius; Pangasianodon hypophthalmus (Naha et al., 2016), causing a mortality of up to $100 \%$ in infected species. These studies mainly investigated hematological and histopathological alterations; however there were no reports about behavioral alterations induced by MAS. Thus, the aim of this study was to evaluate behavioral changes in cultured $O$. niloticus following experimental infection of Aeromonas hydrophilaas as an indicator of fish health.

\section{MATERIAL AND METHOD}

\section{Fish Samples}

A total of 140 O. niloticus individuals with average body weight $(96 \pm 5 \mathrm{~g})$ were provided alive from a fish hatchery, Beni-Suef, Egypt, in late spring season at water temperature $23 \pm 2^{\circ} \mathrm{C}$. They were brought back to the wet laboratory of Fish Department, Faculty of Veterinary Medicine, Beni-Suef University, Egypt. They were acclimatized for 15 days in two fiberglass tanks (800 L each) capacity supplied with chlorine-free tap water and continuous aeration. The fish were fed with standard commercial fish feed with a ratio of $3 \%$ body weight once a day during the acclimatization and experimental study. .

\section{Bacterial Isolate}

Aeromonas hydrophila strain was previously isolated from diseased O. niloticus and identified using API 20E and PCR technique in Department of Fish Disease and Management, Faculty of Veterinary Medicine, Beni-Suef University, Beni-Suef, Egypt and published by (Korni et al., 2017) The hemolysin gene for- ward primer was 5'-GCCGAGCGCCCAGAAGGTGAGTT-3' and the reverse primer was 5'-GAGCGGCTGGATGCGGTTGT-3'. The PCR mixture was $20 \mu \mathrm{L}$ reaction. Volumes of each $(10 \mu \mathrm{L})$ PCR product were subjected to electrophoresis in a $1.5 \%(\mathrm{w} / \mathrm{v})$ agarose gel (Casiano et al., 2010).

\section{Determination of Median Lethal Dose $\left(L_{50}\right)$ of Aeromonas hydrophila Isolate in Healthy $O$. niloticus}

A total of 60 O. niloticus $(96 \pm 5 \mathrm{~g}$ ) were equally divided into 6 groups each of 10 fish An overnight culture of the isolate was adjusted to densities of $1.5 \times 10^{8}$ (group 1), $1.5 \times 10^{7}$ (group 21), $1.5 \times 10^{6}$ (group 3), $1.5 \times 10^{5}$ (group 4), and $1.5 \times 10^{4}$ (group 5), (Korni et al., 2017). Each dilution was injected intraperitoneally (IP) to a fish in each group at a dose of $0.4 \mathrm{ml} /$ fish and the fish of the sixth group was used as control and injected with $0.4 \mathrm{~mL}$ of sterile saline. All fish groups were closely observed for two weeks. Mortality rates were recorded daily, and the organs were aseptically streaked on brain heart infusion agar for re-isolation and re- identification.

\section{Experimental Design of Pathogenicity and Behavior Studies}

A total of120 clinically healthy $O$. niloticus with average body weight $(92 \pm 3 \mathrm{~g})$ were used for monitoring the pathogenicity of A. hydrophila. The identified isolate was inoculated onto BHIA at $28^{\circ} \mathrm{C}$ for 18 hours. Pure bacterial culture was suspended into a sterile saline and adjusted to $1.5 \times 10^{8} \mathrm{CFU} / \mathrm{mL}$. Fifteen days after acclimation; the fish were randomly divided into four equal groups (30 fish/group). Each group was sub-divided into 3 replicates (10 for each). First and second groups were kept for controls and injected IP and IM respectively with $0.4 \mathrm{ml}$ of sterile saline. The third and fourth groups were given IP and IM injections with $0.4 \mathrm{~mL}$ bacterial suspension of $1.5 \times 10^{8} \mathrm{CFU} / \mathrm{mL}$. All fish groups were kept under daily observation for two weeks. Behavior of the fish, clinical signs and mortalities were recorded. All freshly dead fish were submitted to bacteriological isolation and identification of the disease causative agent to verify the specificity of mortality. The present study was approved by Beni-Suef University's Institutional Animal Care and Use Committee (BSU-IACUC).

\section{Behavioral Measurement}

Behavior of injected fish (IP and IM groups) was recorded during the seven consecutive days post injection. The behavior of survived fish in the IM group was observed on fourteenth post injection. Behavior was captured for 15 min session once a day using digital video camera (SONY, Japan). Three videos for each group (one video for each replicate) were recorded. Time of recording was fixed daily (8:00-8:15). Behavior of experimentally infected and apparently healthy fish was analyzed by scan observation (Barlow et al., 2009). Number of opercular movements $\mathrm{min}^{-1}$ of four fish in each aquarium was counted without moving them from aquarium Foraging as shown in Figure 1a and social behavior including aggression (fish bit another; Figure 1b), schooling (at least 4 fish swimming together; Figure 1c), and shoaling (3 fish swimming together; Figure $1 \mathrm{~d}$ ) were analyzed. Abnormal behaviors (stereotypies) were also recorded. Frequencies of all normal and abnormal behaviors were calculated among the recorded videos period (Figure 1e, f). 


\section{Statistical Analysis}

Statistical analyses were performed using Advanced Models 16.0 software Statistical Package for the Social Sciences (SPSS Inc.; Chicago, IL, USA). Behavior data was analyzed using independent t-test. A significant difference between the injected groups and corresponding control is considered if $p<0.05$.

\section{RESULT AND DISCUSSION}

\section{Pathogenicity Test}

Experimentally infected $O$. niloticus in IP and IM injected fish showed signs of septicemia as congested gills, exophthalmia, ocular hemorrhage, disintegration of tail fin (Figure $2 \mathrm{a}, \mathrm{b}$ ) and skin and fin hemorrhages (Figure $2 \mathrm{c}, \mathrm{d}$ ). The post mortem findings of experimentally infected fish reveled congested kidney, liver and spleen. The IP injected fish showed more severe clinical
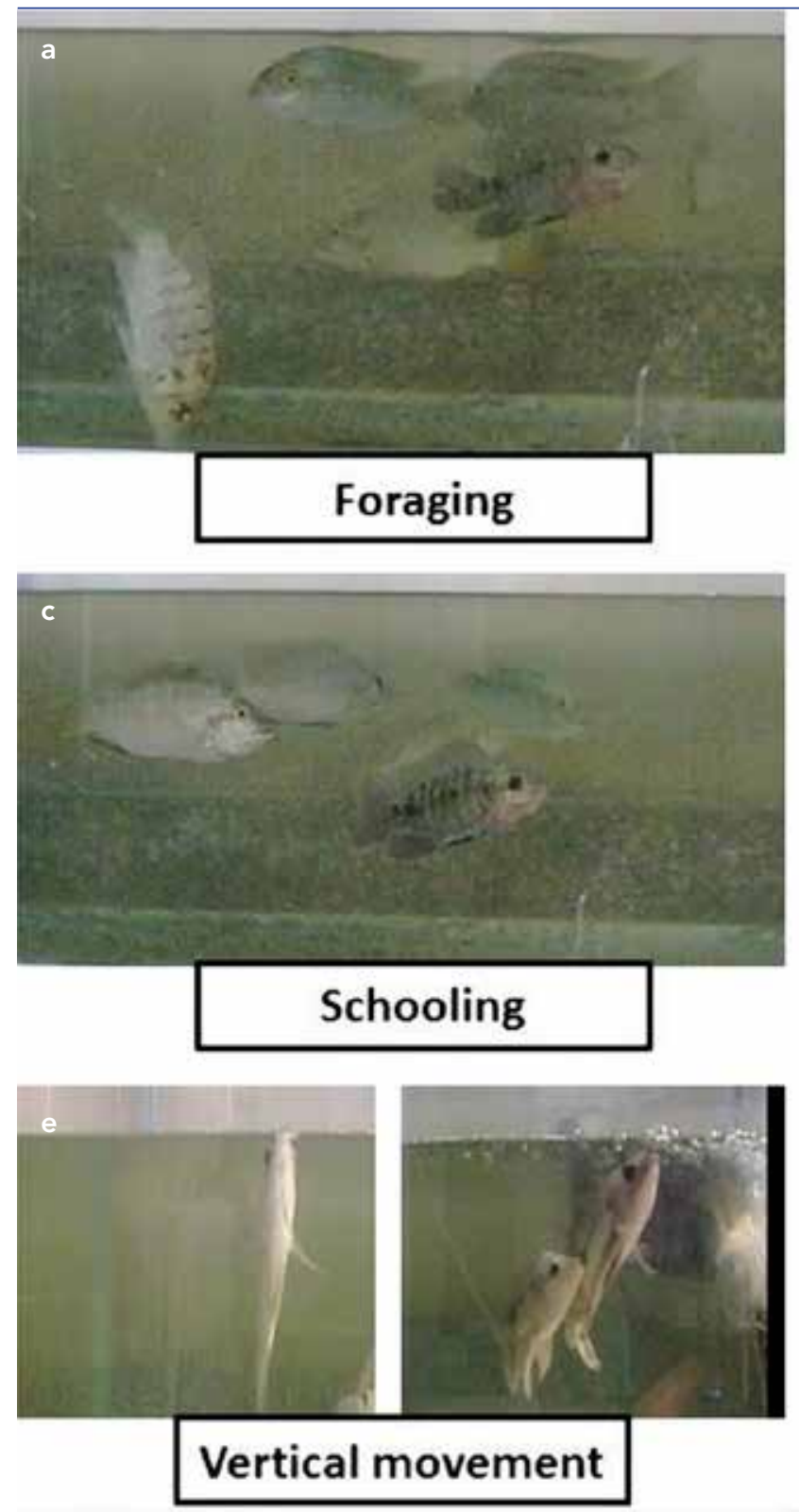

signs and higher mortality rate than IM injected ones (80\%). In the control group, fish showed neither clinical signs nor mortalities (Table 1).

\section{Behavioral Alterations}

Fish showed clinical signs of experimentally induced MAS infection. Fish exhibited cessation of all normal behavioral patterns, aggressed by apparently healthy fish, and gathered around the source of aeration. Moreover, normal behavioral patterns of apparently healthy fish in injected groups (IP and IM) were altered significantly compared to control group. These alterations were in a fluctuating manner among the days of observation post injection.

The rate of bucco-opercular movement $\min ^{-1}$ was significantly increased (hyperventilatory activity) in IP injected fish among all
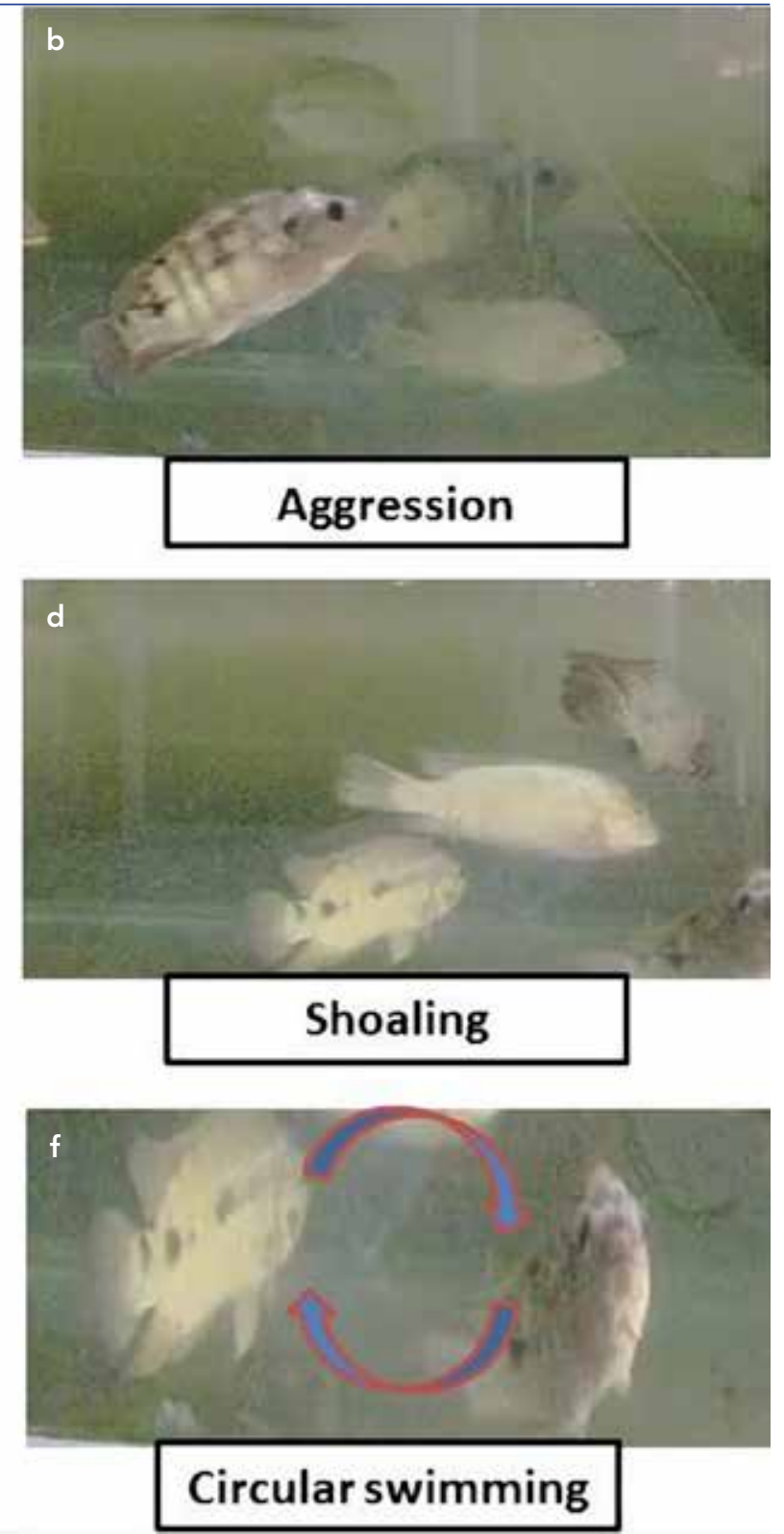

Figure 1. a-f. Normal behaviors (a-d) and stereotypies [abnormal behavior $(e, f)]$ of $O$. niloticus 
days of observation post injection (Figure 3a). In addition, IM injected group exhibited significant hyperventilatory activity on all days of observation except the first fourth and fourteenth days. Furthermore, the IP injected group showed significant decrease in foraging frequency in relation to control fish. Similar results were observed in IM group except on the fourth, fifth, and sixth days post injection (Figure $3 \mathrm{~b}$ ).

Social behavior of IP injected fish was disturbed. Aggression frequency was significantly increased during all the days of observation (Figure 3c), however, shoaling and schooling frequencies significantly decreased on the third, fourth, fifth, sixth, and seventh days compared with the control group (Figure 3d, e). Moreover, IM group showed impaired social behavior and significantly increased aggression among the observation period except on the second and third days post injection (Figure 3b). Shoaling frequency decreased on day fourteen only (Figure 3e), whereas schooling behavior significantly decreased on the third, seventh, and fourteenth days.

Table 2 showed two stereotypies (i.e., circular swimming and vertical movement) of apparently healthy $O$. niloticus. IP injected fish performed circular swimming with frequency of $1.6 \pm 2.3$ and $7.6 \pm 5.5$ on the third and seventh days respectively. IM injected fish exhibited vertical movement with frequency of $2.6 \pm 2$, $4.6 \pm 1.5,13 \pm 7.6$ and $0.3 \pm 0.5$ on the fourth, fifth, seventh and fourteenth days post injection, respectively.

Aeromonads are commonly found in all types of freshwater environments and various motile aeromonas species such as $A$. hydrophila, A. caviae, A. sobria, A. veronii and A. schubertii are pathogens of cultured freshwater fishes, however A. hydrophila, is the main cause of MAS (Akayli et al., 2011; Öztürk and Altınok 2014).
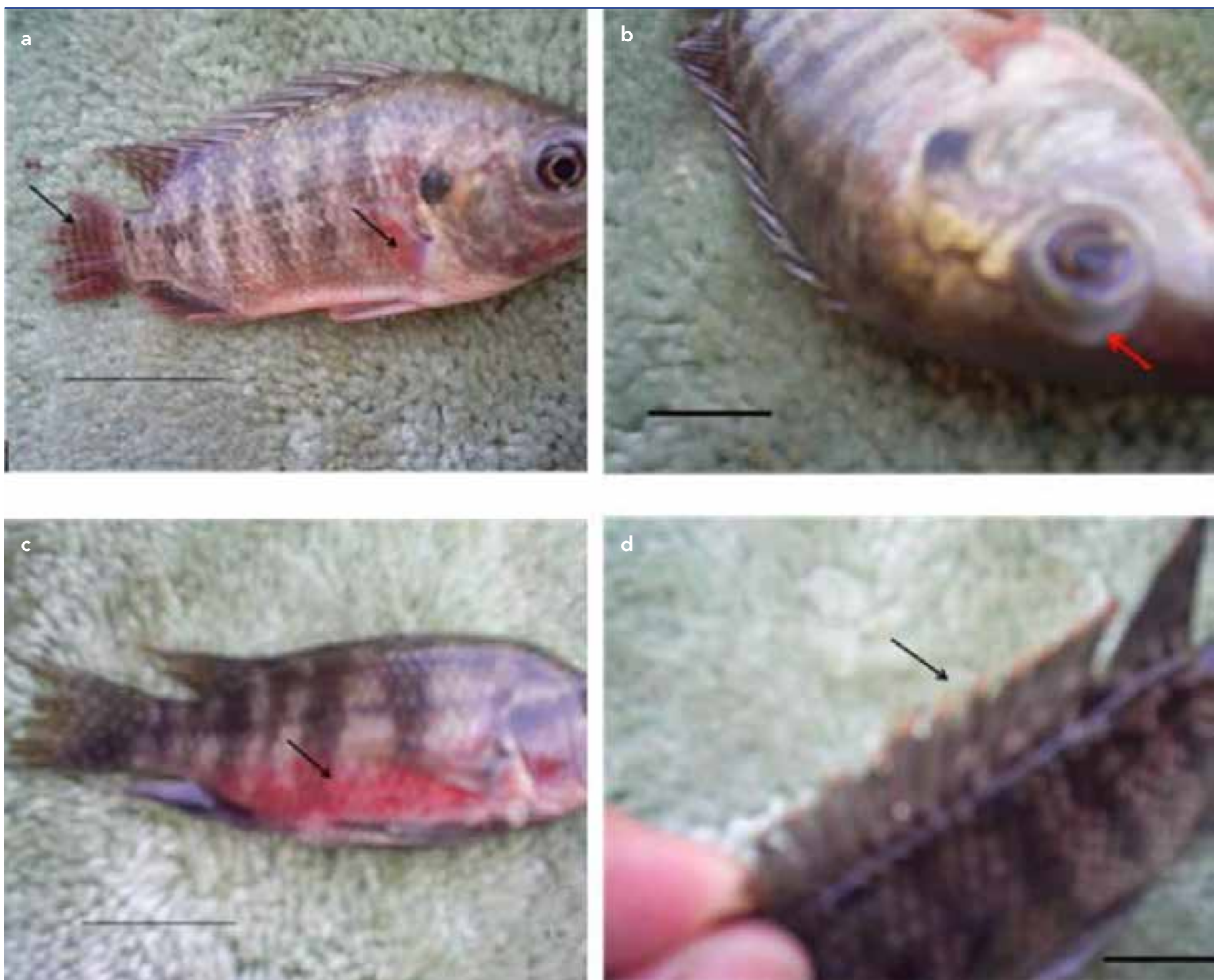

Figure 2. a-d. Clinical signs of motile Aeromonas septicemia in experimentally infected O. niloticus. (a). ocular hemorrhages, hemorrhage at pectoral fin base and disintegration of caudal fin (Scale bar $0.75 \mathrm{~cm}$ ). (b). exophthalmia (Scale bar $1 \mathrm{~cm}$ ). (c). severe hemorrhages on the skin (Scale bar $0.5 \mathrm{~cm}$ ). (d). at dorsal fin $(S c a l e ~ b a r ~ 1 \mathrm{~cm})$ 
Table 1. Mortality \% of $O$. niloticus caused by experimentally induced MAS.

\begin{tabular}{lccc}
\hline & \multicolumn{3}{c}{ Mortality\% } \\
\hline $\begin{array}{l}\text { Day post } \\
\text { injection }\end{array}$ & Control & $\begin{array}{c}\text { Ip injected } \\
\text { group }\end{array}$ & $\begin{array}{c}\text { Im injected } \\
\text { group }\end{array}$ \\
\hline $1^{\text {st }}$ & 0 & 25 & 0 \\
$2^{\text {nd }}$ & 0 & 26 & 0 \\
$3^{\text {rd }}$ & 0 & 29 & 0 \\
$4^{\text {th }}$ & 0 & 37,5 & 20 \\
$5^{\text {th }}$ & 0 & 40 & 18,7 \\
$6^{\text {th }}$ & 1 & 33 & 153 \\
$7^{\text {th }}$ & 3 & 50 & 9 \\
$1^{\text {th }}$ & 3 & 100 & 0
\end{tabular}

Table 2. Stereotypies of $O$. niloticus caused by; control group (injected with $0.4 \mathrm{~mL}$ saline), IP (injected $0.4 \mathrm{~mL}$ of bacterial suspension of $1.5 \times 10^{8} \mathrm{CFU} /$ $\mathrm{mL}$ ) and IM (injected with $0.4 \mathrm{~mL}$ of bacterial suspension of $1.5 \times 10^{8} \mathrm{CFU} / \mathrm{mL}$ )

\begin{tabular}{lccc}
\hline Group & Stereotypies & $\begin{array}{c}\text { Day of onset } \\
\text { post injection }\end{array}$ & Frequency \\
\hline Ip & Circular swimming & $3^{\text {rd }}$ & $1.6 \pm 2.3$ \\
& & $7^{\text {th }}$ & $7.6 \pm 5.5$ \\
Im & Vertical movement & $4^{\text {th }}$ & $2.6 \pm 2$ \\
& & $5^{\text {th }}$ & $4.6 \pm 1.5$ \\
& $7^{\text {th }}$ & $13 \pm 7.6$ \\
& $14^{\text {th }}$ & $0.3 \pm 0.5$
\end{tabular}
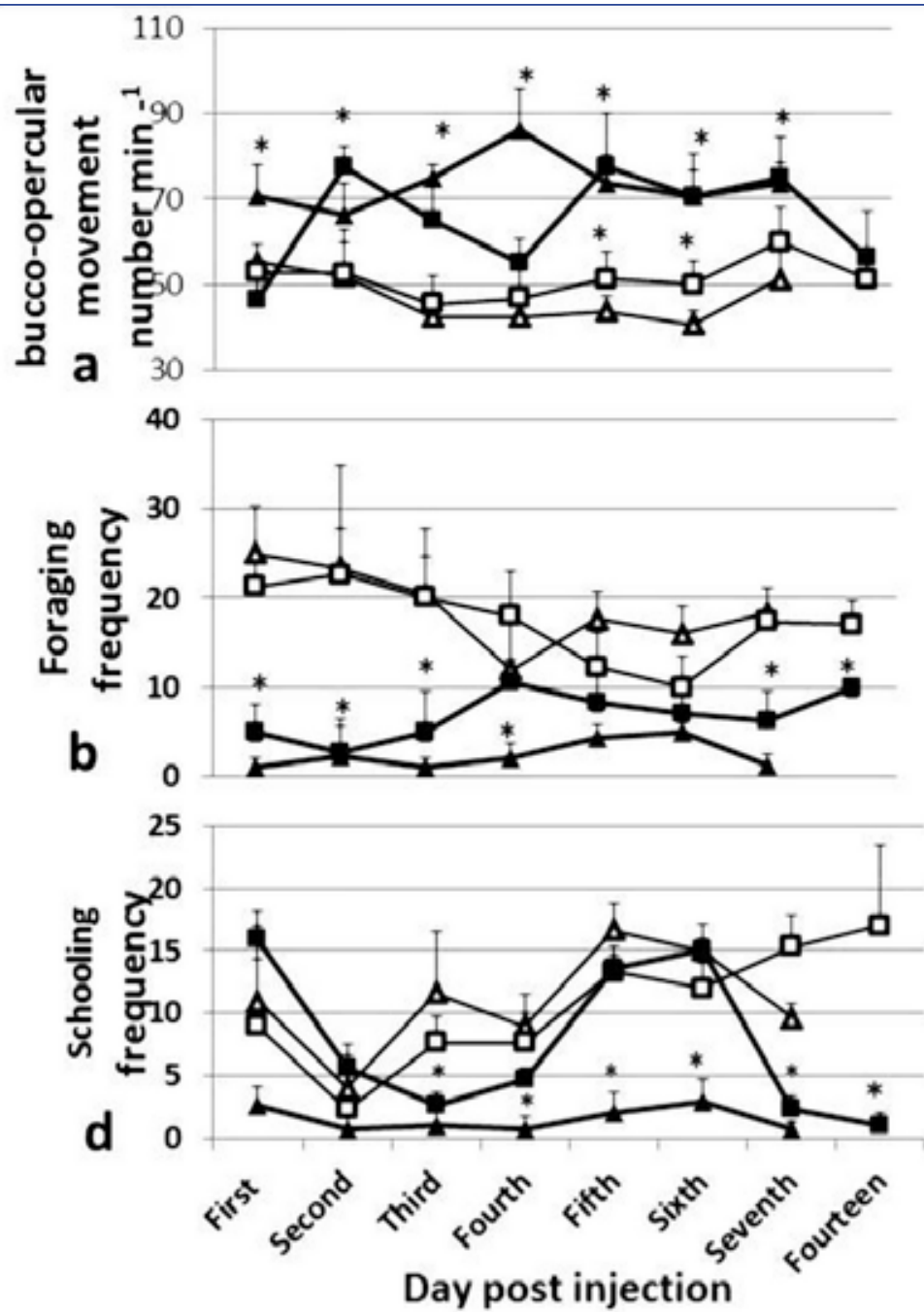

\section{IP \\ $\rightarrow \quad$ IP $\quad$ injected with \\ A.hydrophila \\ IM \\ -o $\underset{\text { Control }}{\mathrm{IM}}=$ injected with}

\section{A.hydrophila}
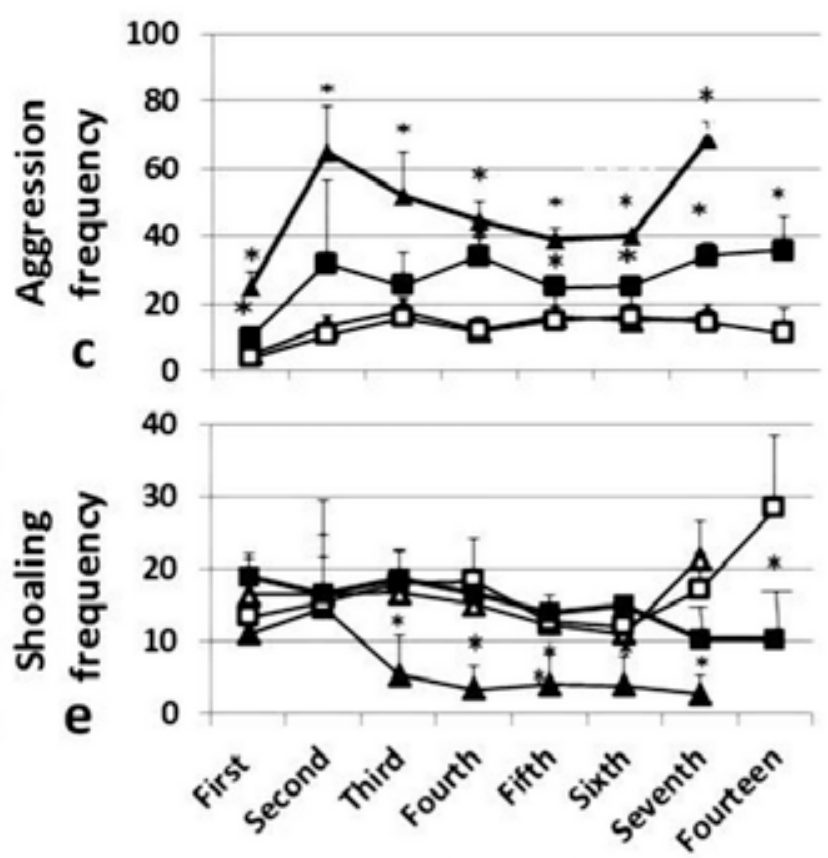

Day post injection

Figure 3. a-e. Effect of experimentally induced MAS (A. hydrophila) on behavior of min -1 O. niloticus, Control group (injected with $0.4 \mathrm{~mL}$ saline), IP (injected $0.4 \mathrm{~mL}$ of $1.5 \times 10^{8} \mathrm{CFU} \mathrm{mL}$ ) and IM (injected with $0.4 \mathrm{~mL}$ of $1.5 \times 10^{8}$ $\mathrm{CFU} / \mathrm{mL})$. All values are the mean $\pm \mathrm{SD}(\mathrm{n}=3)$. The asterisk $\left(^{*}\right)$ indicates a significant difference between the injected groups and corresponding control (white blot) according to independent $t$ test at $p<0.05$ 
In this study, extracellular products secreted by the causative agent of MAS disease (A. hydrophila) were responsible for pathogenicity. In addition, the reported signs of septicemia are attributed to the presence of hemolysis virulence gene in the isolate. Kristiansen and Fernö (2007) recorded higher mortality in IP injection. Moreover, Sarker (2009) recorded mortalities reached to $100 \%$ in IP and IM injected carp and perch.

Concerning the behavioral data, experimentally infected fish showing the clinical signs of MAS stopped performance of all normal behavioral patterns. Cessation of such behaviors is a common indicator of fish sickness (Martins et al., 2012). In addition, diseased fish stayed near aeration source due to hypoxia caused by gills inflammation (Noga 2011). Infected fish with bacteria showed different abnormal swimming patterns such as erratic swimming, whirling on the surface, and C-shaped body curvature at the surface in Red tilapia and mullet infected with streptococci (Evans et al., 2002; Zamri-Saad et al., 2010).

Normal behavioral patterns of apparently healthy fish in injected groups (IP and IM) were altered significantly compared to control. These alterations were in a fluctuating manner among the days of observation post injection. The reported behavior of apparently healthy fish in IP injected group revealed an acute form of the behavioral response to pathogens and stressors (Martins et al., 2012). The observed hyperventilatory activity may be attributed to the gill congestion or low hematocrit (White et al. 2008). This is an attempt from the fish's internal environment (homoeostasis) to maintain oxygen $\left(\mathrm{O}_{2}\right)$ status, blood and tissue acid-base balance (pH) (Martins et al., 2012). The observed hyperventilatory activity was supported the findings of Noga (2011) and Khalil et al. (2017). Hyperventilatory activity may result from many biotic and abiotic stressors (Martins et al., 2012; Khalil et al., 2017). Therefore, rate of bucco-opercular movement could be linked with other welfare indicators in the fish ponds such as water quality, blood lactate, glucose, and hematocrit (Martins et al., 2012; Noga, 2011, Khalil et al., 2017) as well as other behavioral changes to achieve an accurate interpretation of hyper/ hypoventilatory activity.

Our data revealed decrease of foraging behavior of apparently healthy fish. This is may be due to stress posed by infection and impairment of fish social behavior (Krause and Ruxton, 2002; Martins et al., 2012; Kujur and Parganiha, 2013). These data were similar to that observed on $O$. niloticus suffered from a piscirickettsiosis-like condition (Mauel et al., 2007) and in Atlantic salmon suffered from vibriosis (Danchin et al., 2008). Decrease of feeding behavior is a sensitive indicator to health status of fish that leads to reduction of growth and reproduction (Volkoff et al., 2010).

The results of this study showed that, the impairment effect of MAS disease on social behavior of fish expressed in an increase of aggression bouts and a decrease of group swimming (schooling and shoaling) frequency, reduction of schooling and shoaling might be attributed to the decrease of individual movement induced by parasitic infestation as reported in Atlantic salmon (Wagner et al., 2003), Sockeye salmon Oncorhynchus nerka (Tierney and Farrell, 2004) and Bull trout Salvelinus confluentus (Jones and Moffitt, 2000). Fish aggregation is controlled by visual clues
(Ruhl and McRobert, 2005), hence the observed decrease shoaling and schooling may be attributed to eye lesions caused by aeromonous hydrophilla.

Although increased aggression is an indicator of fish health and welfare, it must be accompanied with scars and lesions on the bitten fish (Martins et al., 2012). Social behavior enhance foraging, reproducion, and protection against predators (Krause and Ruxton, 2002; Kujur and Parganiha, 2013). Thus, social behavior alterations were usually used for assessment of fish health and welfare.

Circular swimming and frequencies increased over time, however, frequency of vertical swimming was decreased on the fourteenth day. On the fourth, fifth and sixth day post injection, mortalities were $37.5 \%, 40 \%$ and, 33\% while, foraging, schooling, and shoaling showed no significant alterations in relation to the control fish. This indicated that, all fish that had exhausted resistance to infection during these three days died while fish that were still resisting infection performed the recorded normal behavior. Thus, behavior reflects immunity competence of fish.

The observed circular swimming (stereotypes) in IP injected fish was similar to that performed by African catfish as an indicator to stress (Almaza'n-Rueda et al., 2004). This behavioral pattern was almost followed by a high mortality on the third (27\%) and seventh (50\%) day. Furthermore, vertical swimming was recorded in the IM injected group. This behavior might be exhibited by fish due to hypoxia caused by gills inflammation (El-Araby et al., 2016), though no clinical signs of disease were observed. We hypothesize that, the recorded time-dependent increase of the recorded stereotypes frequency may indicate an increase of fish attempts to resist pathogen until exhaustion/failure that ended by mortality. The observed behavioral changes of apparently healthy fish may be a nonspecific response to MAS, however, it may be used as a useful, fast and non-invasive tool to assess and predict the resulted economic losses of the disease before occurrence of mortalities. Retardation of growth and reproduction is highly expected due to impairment of critical behaviors such as swimming, foraging, and schooling.

\section{CONCLUSION}

These results revealed that, MAS had a serious effect on the behavior of apparently healthy fish. Consequently, severe economic losses are predicted, such as retarded fish growth and decreased reproduction. Moreover, data suggests behavior measurement of Nile tilapia as a useful and fast and non-invasive tool for early diagnosis of the bacterial disease (specially MAS) in aquaculture.

Ethics Committee Approval: Ethics committee approval was received for this study from the ethics committee of Beni-Suef University's (Institutional Animal Care and Use Committee; BSU-IACUC).

Acknowledgements: We thank Dr. Fatma Korni, Department of Fish Disease and Management Faculty of Veterinary Medicine, Beni-Suef University, Beni-Suef, Egypt for supplement of the Aeromonas hydrophila isolates that she isolated and identified.

Conflict of Interest: The authors have no conflicts of interest to declare. 


\section{REFERENCES}

Akaylı, T., Çanak, O., Başaran, B. (2011). Gökkuşağı alabalıklarında (Oncorhynchus mykiss Walbaum, 1792) görülen Aeromonas schubertii enfeksiyonu üzerine bir çalışma. Biyoloji Bilimleri Araştırma Dergisi, 4(1): 99-106.

Almaza'n-Rueda, P., Schrama, J.W., Verreth, J.A.J. (2004). Behavioural responses under different feeding methods and light regimes of the African catfish (Clarias gariepinus) juveniles. Aquaculture Journal, 23: 347-35. [CrossRef]

Banu, Y., A. Yılmaz. (2011). Pathological findings of experimental Aeromonas hydrophila infection in Nile tilapia (Oreochromis niloticus). Ankara Üniversitesi Veteriner Fakültesi Dergisi, 58:47-54. [CrossRef]

Barlow, D.H., Nock, M., Hersen, M. (2009). Single case experimental designs: Strategies for studying behavior for change (No. Sirsi) i9780205474554).

Casiano, H., Choresca, J.R., Dennis, K., Gomez, J.E., Han, S.S., Ji-Hyung, K., Jin-Woo, J., Se-Chang, P. (2010). Molecular detection of A. hydrophila isolated from albino catfish, Clarias sp. reared in an indoor commercial aquarium. Korean Journal of Veterinary Research, 50 (4): 331-333.

Danchin, E., Giraldeau, L., Ce'zilly, F. (2008). Behavioural ecology. Oxford University Press, Oxford.

El-Araby, D.A., El-Didamony, G., Megahed., M.T.H (2016). New Approach to Use Phage Therapy against Aeromonas hydrophila Induced Motile Aeromonas Septicemia in Nile Tilapia. Journal of Marine Science: Research and Development 6: 194.

Evans, J. J., Klesius, P. H., Gilbert, P. M., Shoemaker, C. A., Al Sarawi, M. A., Landsberg, J., \& Al Zenki, S. (2002). Characterization of $\beta$-haemolytic Group B Streptococcus agalactiae in cultured seabream, Sparus auratus L., and wild mullet, Liza klunzingeri (Day), in Kuwait. Journal of Fish Diseases, 25(9): 505-513. [CrossRef]

Faucher, K.E., C. Parmentier, C. Becco, N. Vandewalle, Vandewalle, P. (2010). Fish lateral system is required for accurate control of shoaling behaviour. Animal Behavior, 79: 679-687. [CrossRef]

Jones, D.T., Moffitt, C.M. (2000). Swimming endurance of bull trout, lake trout, Arctic char, and rainbow trout following challenge with Renibacterium salmoninarum. Journal of Aquatic Animal Health, 16: 10-22. [CrossRef]

Khalil, F., Kang, I.J., Undap, S, Tasmin, R., Qiu, X. Shimasaki, Y., Oshima, Y. (2013). Alterations in social behavior of Japanese medaka (Oryzias latipes) in response to sublethal chlorpyrifos exposure. Chemosphere Journal 92(1): 125-130. [CrossRef]

Khalil, F., Korni, F. (2017). Evaluation of moringa Oleifera Leaves and their aqueous extract in improving growth, immunity and mitigating effect of stress on Common Carp (Cyprinus Carpio) fingerlings. Turkish Journal of Aquatic Sciences, 32(3): 170-178. [CrossRef]

Kujur, P., Parganiha, A. (2013). Social Interaction in Fish: A Brief Review. Journal of Ravishankar University-B, 26-34.

Korni, F.M.M. (2015). Diagniosis of motile Aeromonas septicemia in Catfish (Clarias gariepinus) and its trial for prevention in Nile tilapia (Oreochromis niloticus). Global Journal of Fisheries and Aquaculture Researches, 2: 47-63.

Korni, M.M.F, Nahass, E. El., Ahmed, M.S.W. (2017). An outbreak of Motile Aeromonas Septeciemia in cultured Nile Tilapia, oreochromis niloticus with reference to hematological, biochemical and histopathological alterations. Journal of Fish Patholoogy, 30(1): 11-24.
Krause, J., Ruxton, G. (2002) Living in Groups. p. 224. USA, Oxford University Press.

Kristiansen, T.S., Fernö, A. (2007). Individual behaviour and growth of halibut (Hippoglossus hippoglossus L.) fed sinking and floating feed: evidence of different coping styles. Applied Animal Behaviour Science Journal, 104: 236-250. [CrossRef]

Mason, G. J. (1991) Stereotypies: a critical review. Animal Behaviour 41(6): 1015-1037. [CrossRef]

Martins, C.I., Galhardo, L., Noble, C., Damsgård, B., Spedicato, M.T., Zupa, Kristiansen, T. (2012). Behavioural indicators of welfare in farmed fish. Fish Physiology and Biochemistry Journal, 38(1): 17-41. [CrossRef]

Nahar, S., Mohammad, M. R., Ahmed, G. U., Faruk, M A.R. (2016). Isolation, identification and characterization of Aeromonas hydrophila from juvenile farmed pangasius (Pangasianodon hypophthalmus). International Journal of Fisheries and Aquatic Studies, 4(4): 52-60.

Noga, E. J. (2011). The Clinical Workup. In Fish disease: diagnosis and treatment. John Wiley and Sons.pp.18.

Öztürk, R.Ç., Altınok, I. (2014). Bacterial and Viral Fish Diseases in Turkey. Turkish Journal of Fisheries and Aquatic Sciences 14: 275-297. [CrossRef]

Ruhl, N., McRobert, S.P. (2005). The effect of sex and shoal size on shoaling behaviour in Danio rerio. Journal of Fish Biology, 67: 1318-1326. [CrossRef]

Pavanelli, G.C, Eiras , J.C., Takemoto, R.M. (2008). Doenças de Peixes: profilaxia, diagnóstico e tratamento. $3^{a}$ ed. p. 311 (ed by Eduem).

Pavlov, D.S., A.O., Kasumyan (2000). Patterns and mechanisms of schooling behavior in fish: a review. Journal of Ichthyology, 40: 51-63.

Pridgeon J.W., Klesius, P.H. (2011). Molecular identification and virulence of three Aeromonas hydrophila isolates cultured from infected channel catfish during a disease outbreak in west Alabama (USA). Disease of Aquatic Organisms, 94: 249-53. [CrossRef]

Pridgeon, J.W., Klesius, P.H. (2012). Major bacterial diseases in aquaculture and their vaccine development. CAB Reviews, 7: 48. [CrossRef]

Sarker, J.A. (2009). Experimental infections of carps, perch and catfishes with Aeromonas hydrophila bacteria. M. S. Thesis, Department of Aquaculture, Bangladesh Agricultural University, Mymensingh. 47 p.

Tierney, K.B., Farrell, A.P. (2004). The relationships between fish health, metabolic rate, swimming performance and recovery in return-run sockeye salmon, Oncorhynchus nerka (Walbaum). Journal of Fish Disease 27: 663-671. [CrossRef]

Vestergaard, K. (1981) Influence of fixation on the behaviour of sows. In: The Welfare of Pigs (Ed. by W. Sybesma), pp. 16-30. [CrossRef]

Volkoff, H., Hoskins, L. J., Tuziak, S.M. (2010). Influence of intrinsic signals and environmental cues on the endocrine control of feeding in fish: potential application in aquaculture. General and Comparative Endocrinology 167(3): 352-359. [CrossRef]

Wagner, G.N., McKinley, R.S., Bjørn, P.A., Finstad, B. (2003). Physiological impact of sea lice on swimming performance of Atlantic salmon. Journal of Fish Biology, 62: 1000-1009. [CrossRef]

White, A.J., Schreer, J.F., Cooke, S.J. (2008). Behavioral and physiological responses of the congeneric largemouth (Micropterus salmoides) and smallmouth bass (M. dolomieu) to various exercise and air exposure durations. Fisheries Research Journal, 89: 9-16. [CrossRef]

Zamri-Saad, M., Amal, M. N. A., Siti-Zahrah, A. (2010). Pathological changes in red tilapias (Oreochromis spp.) naturally infected by Streptococcus agalactiae. Journal of Comparative Pathology, 143(23): 227-229. [CrossRef] 